\section{MODERN PRACTICE IN ANAESTHESIA}

Edited by Frankis T. Evans, M.B., B.S., F.F.A.R.C.S., D.A. 2nd Edition. Pp. xv + 645 with 221 illustrations. London: Butterworth \& Co. Ltd. I954. 65s.

It is a pleasant task to welcome the second edition of this popular textbook of anaesthetics. Like most books compiled from many authors, the standard varies from chapter to chapter, but in this new edition excellent new chapters on the "The Principles of Muscular Relaxation' and the 'Muscle Relaxants' have helped to place this subject in its correct perspective-in the forefront of modern anaesthesia.

In a book which so obviously sets out to be comprehensive and to set a standard for modern teaching it is a pity that throughout the text all drugs are described by their ' trade names' rather than by their correct pharmacopoeal nomenclature. Such popular misconceptions as 'adrenaline raises the blood pressure by vasoconstriction,' 'Tensilon possesses litt'e anticholinesterase activity' and 'severe bleeding causes renal vasoconstriction' are but few of the small errors in an otherwise praiseworthy book.

$$
\text { H.C.C-D. }
$$

\section{EXPERIMENTAL DIABETES AND ITS RELATION TO THE CLINICAL DISEASE}

Edited by J. F. Delafresnaye and G. Howard Smith. Pp. ix +352 , illustrated. Oxford: Blackwell Scientific Publications. 1954. 35 s.

This volume contains 22 separate papers contributed by a distinguished body of scientists and clinicians, each an acknowledged master in the field of diabetes. A summary of all relevant fact relating to experimental diabetes is presented, together with many highly interesting hypotheses which must stimulate thought and provoke speculation in respect of the clinical disease. It must be said at the outset that for the practising physician, be he consultant or general practitioner, this must remain a reference book, albeit an excellent one. The very quality of the work, maintained at an unusually high standard throughout, close packed as it is with factual knowledge, presented in highly technical language which assumes a basic knowledge which many must lack, prevents any attempt at steady reading. Further, the scope covered is too great for assimilation at a single sitting, no matter how far prolonged. Close attention to one or to several chapters in sequence, however, cannot fail to reward. The emphasis is on the genesis of diabetes and especially through the three agencies of glucagon, of alloxan and of growth hormone, though steroid diabetes is amply covered and clinical problems such as the influences of pregnancy and of heredity are included and a clinical classification put forward. Glucagon, otherwise known as the hyperglycaemic-glycogeno- lytic factor, is here virtually accepted as a true hormone secreted by the alpha cells of the islets of Langerhans, its function to offset hypoglycaemia an\& as well possibly to effect transfer of carbohydrate from central stores in the liver to the periphera秀 tissues for utilization. Growth hormone, clearly shown to be the most powerful diabetogenic agent of the anterior pituitary, though not the sole one may act by continued stimulus to overproduction of insulin, with consequent exhaustion of the bet 1 cells, at first reversible, later irreversible. It is shown that the two hormones insulin and growth. hormone must act in harmony for many physio? logical effects including nitrogen retention and in $=$ deed growth itself. Alloxan may damage the bets cells through inactivation of certain essential enzymes systems, probably those possessing free sulphydry groups and the argument that this agent, alloxan. could damage each and every cell of the bod according to its dependence or not on the precises enzyme system implicated opens fresh lines ộ. thought. That this substance or some near relationt may occur in physiological conditions is hinted a but no proof forthcoming. Understanding of eacR problem as it arises is aided by valuable discussions following each paper and obscure or ambiguous points are thus often clarified. These are of speciat value to the scientifically less initiated. Lastlys there is an admirable final review subscribed by the discriminating chairman, F. G. Young. No on= mediate help in the practical management diabetes mellitus is forthcoming, but this does got detract in any way from the excellence of a boplo which offers a wealth of material to all concerned io the study of diabetes mellitus.

\section{THE ECZEMAS}

\section{A Symposium by Ten Authors}

Edited by L. J. A. Loewenthal, M.D., M.R.C.P. D.T.M. \& H. Pp. vii +267 , with 77 illustra? tions. Edinburgh: E. \& S. Livingstone, Ltd I954. 35s.

Here is a sincere attempt to bring together, undeg one cover, modern knowledge about a difficult sub 3 ject. The young dermatologist especially will bढ़ grateful to Dr. Loewenthal, for with this book he will be able to steer safely through troubled water in the comfort of his armchair. The most satisfying. chapters of the symposium are those embodying mainly experimental work, namely Haxthausen's, Burckhardt's and Storck's, but these will be heavs going for the general practitioner for whom the्E book is also intended.

If, then, this valuable book requires criticism it must be mainly on this score. The principat reader is likely to be the dermatologist, establisheक or in training. Too much ground is covered, albeit efficiently, on the clinical side with which heis already familiar. 